\title{
Physic-Chemical Evaluation of Urban Wastewater of the Town of Sidi Kacem
}

\author{
Omar El Rhaouat ${ }^{1}$, Imane El Kherrati ${ }^{1}$, Fatiha El khayyat ${ }^{1}$, Hamid Chiguer ${ }^{1}$, Karima Ezziani ${ }^{2}$, \\ Abdalsalam Ibeda ${ }^{1}$, Mostafa Fareh ${ }^{1}$, Youssef Saidi ${ }^{3}$, Khadija El Kharim ${ }^{1}$, Driss Belghyti ${ }^{{ }^{*}}$ \\ ${ }^{1}$ Laboratory of Environment and Renewable Energies, Faculty of Science, University Ibn Tofail, Kenitra, Morocco \\ ${ }^{2}$ National Office of Drinking Water, Rabat, Morocco \\ ${ }^{3}$ Office of Technical Studies, Rabat, Morocco \\ Email: "belghyti@hotmail.com, el-omo@hotmail.com
}

Received September 17, 2013; revised October 17, 2013; accepted October 24, 2013

Copyright (C) 2014 Omar El Rhaouat et al. This is an open access article distributed under the Creative Commons Attribution License, which permits unrestricted use, distribution, and reproduction in any medium, provided the original work is properly cited. In accordance of the Creative Commons Attribution License all Copyrights (C) 2014 are reserved for SCIRP and the owner of the intellectual property Omar El Rhaouat et al. All Copyright (C 2014 are guarded by law and by SCIRP as a guardian.

\section{ABSTRACT}

The goal of this study is the evaluation of pollution by the physic-chemical characterization of urban wastewaters discharged in the river R'dom of the town Sidi Kacem. The motivation of this study is multiple firstly to give an answer to the choice of methods of treatment of raw sewage and secondly to raise awareness of the pollution of the river R'dom who is a source of irrigation in the region. The physic-chemical analyses were carried out on the level of the collector 1 (domestic collector of the Zaouia District) and that of collector 2 (domestic collector of the allotments Thami Amar, road of Tangier and Saada), during the year 2012 at the same time "in situ" and at the Laboratory of Environment (Faculty of Sciences Kenitra). The polluting load out of organic matter $\mathbf{( D B O}_{5}, \mathrm{DCO}$, MES), out of mineral matter $\left(\mathrm{Cl}^{-}, \mathrm{Ca}^{2+}, \mathrm{Mg}^{2+}, \mathrm{K}^{+}, \mathrm{PO}_{4}^{3-}, \mathrm{Na}^{+}\right)$and out of nitrogenized matter $\left(\mathrm{NO}_{3}^{-}, \mathrm{NH}_{3}^{+}, \mathrm{Ni}-\right.$ trogenize total) was more important, except for the temperature and of the $\mathrm{pH}$ which are in conformity with the Moroccan standards of rejection. Ratios $\mathrm{DCO} / \mathrm{DBO}_{5}, \mathrm{DBO}_{5} / \mathrm{DCO}$ and $\mathrm{MES} / \mathrm{DBO}_{5}$ inform about the biodegradability of these effluents and permitted choice of the suitable treatment process. Indeed, results obtained show that the domestic effluents exceed the national standards of rejection, which requires an intervention of the competent jurisdictions in order to preserve the public health, to protect the environment and install an efficient sewage treatment plant to ensure a sustainable development.

\section{KEYWORDS}

Wastewaters; Physic-Chemistry; Pollution; Sidi Kacem; Morocco

\section{Introduction}

Unpurified domestic wastewaters represent the main source of organic pollution of waters [1]. They procreate a deterioration of the quality of surface and underground waters. Across the whole world, the consumption of the water always knows an exponential expansion; it draws away permanently an increase of the debit of polluting rejections in receiving environment [2].

Indeed, superficial and underground waters are touched in full whip by more and more increased pollution, this last is at the origin of different diseases that can corrupt

\footnotetext{
${ }^{*}$ Corresponding author.
}

gravely human health and balance of ecosystems.

The present study, taking place in the course of year 2012 is recommended to assess the largeness of pollution of these urban effluents of Sidi Kacem City (Morocco) towards the receiving environment receiving significant wastewaters discharge. In order to do that, we had recourse to physicochemical analyses accomplished at the level of these two domestic collectors.

\section{Equipment and Method}

\subsection{Zone of Study (Figures 1 and 2)}

Our study was led on the rejection of urban wastewaters directly in the river R'dom who crosses a part of the pro- 


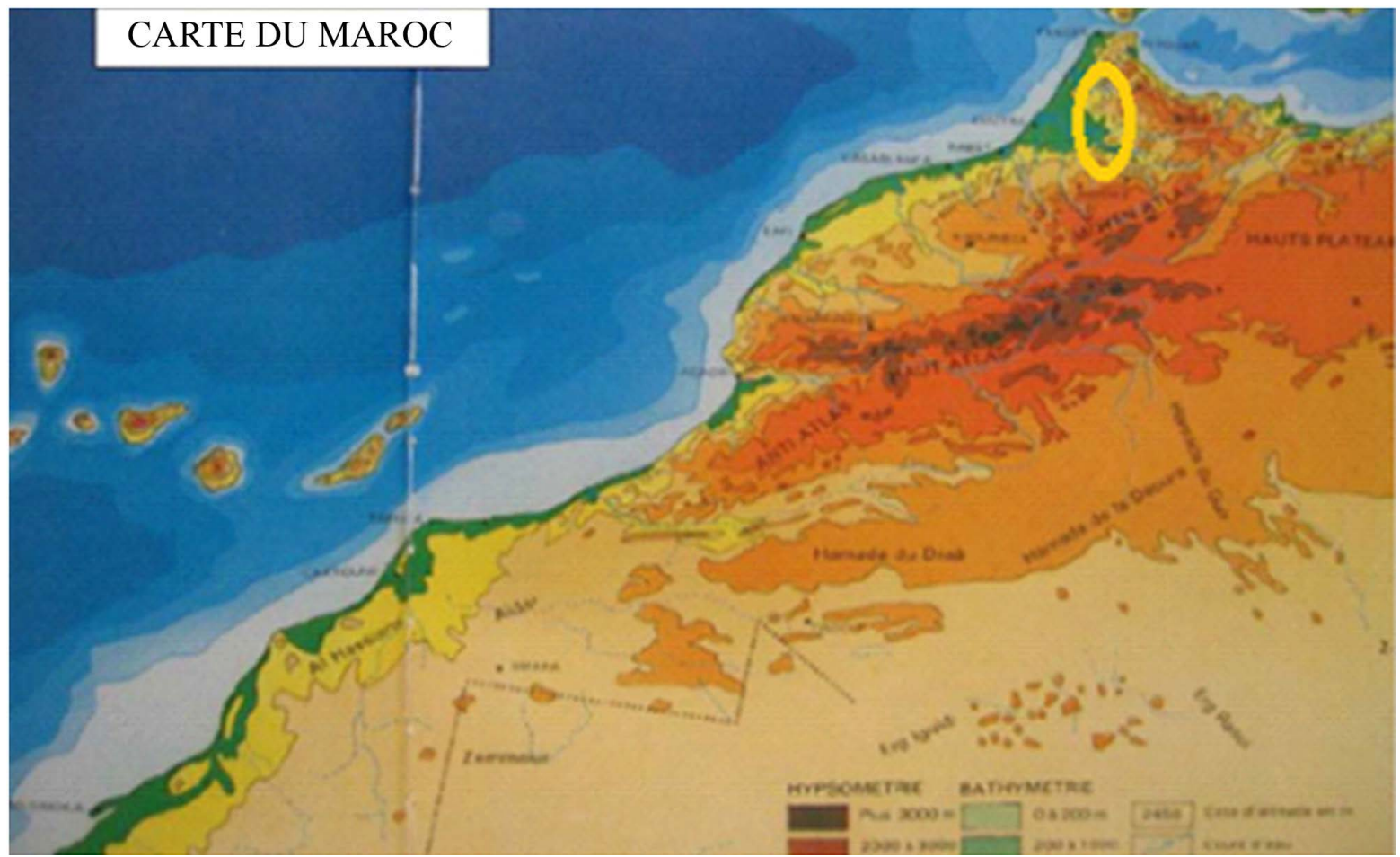

Figure 1. Chart of Morocco with localization of the irrigated perimeter of Gharb [3].

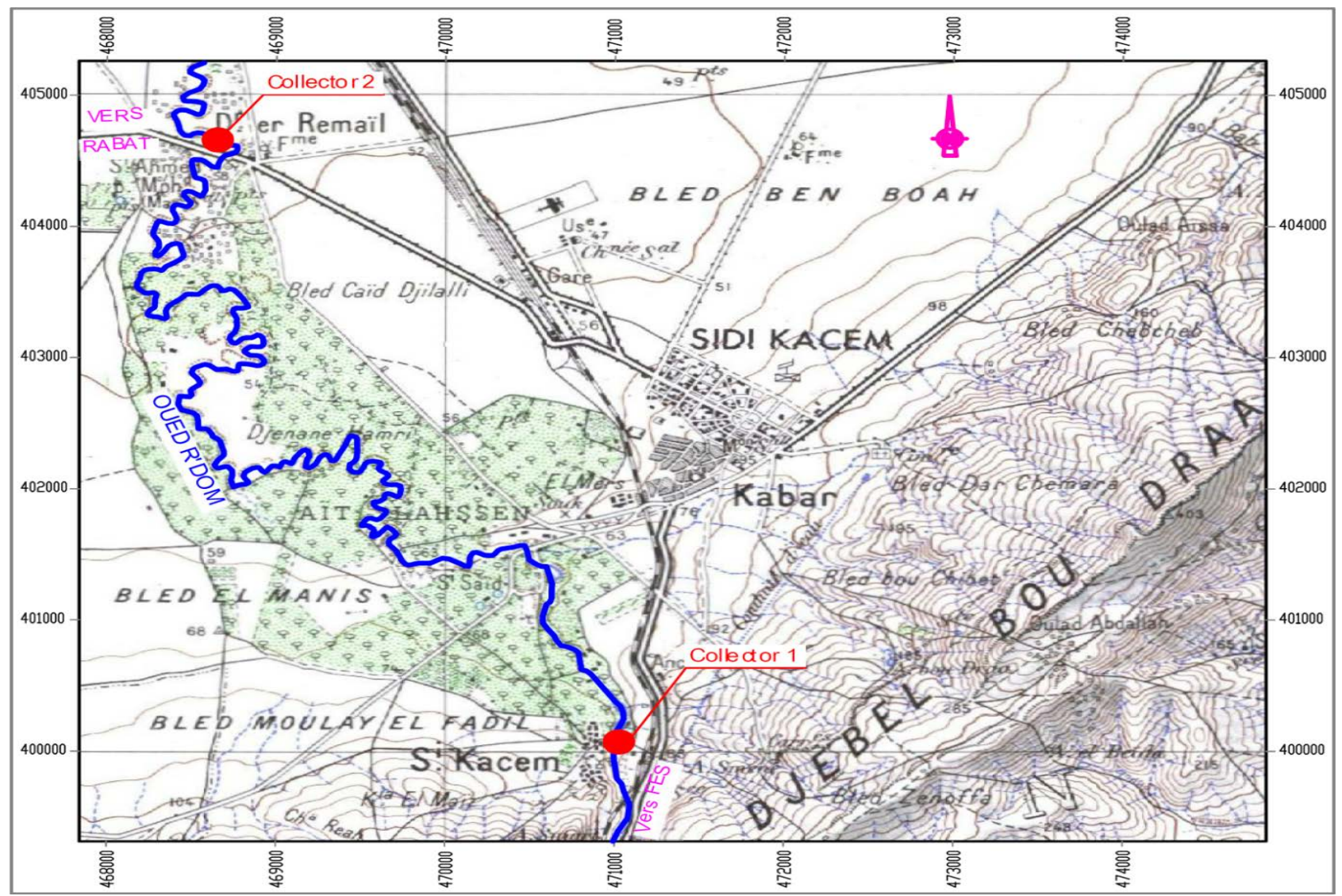

Figure 2. Extract of the geographical map of the town of Sidi Kacem. Scale: 1/50,000. Flle. $\mathbf{N}^{\circ}$. N1-30-XIII-1b (Ministry of Agriculture, Morocco). 
vince of Sidi Kacem which is its county seat creates in 1981 [4]. This last is in the region of the Gharb Chrarda Beni Hsen, having a resource in underground water which is part of the tablecloth of Gharb [5]. This province is a $4060 \mathrm{~km}^{2}$, representing $5.7 \%$ areas of the national territory. The population attains about 701,000 inhabitants among whom 74,062 are inhabitants of the Sidi Kacem city [6].

On hydrologic plan, the watershed of the river Beht has an area of $9000 \mathrm{~km}^{2}$, receives the river R'dom before joining river Sebou in the plain of Gharb [7].

Climate is of semiarid Mediterranean type with tempered winter. The annual rainfall is $445 \mathrm{~mm}$. The dry period is relatively long and spreads out from May till September with a medium varying temperature of $11^{\circ} \mathrm{C}$ in December to $29^{\circ} \mathrm{C}$ in August [4].

\subsection{Methods}

During the period of our study, we had recourse to samplings in a periodic way, at the level of the domestic collectors 1 and 2.

Most part of the qualitative and quantitative analyses is accomplished in situ and in the laboratory. These samples took place in the zone of flow of sewers, where the circulation of the water is the most active. We used bottles in polyethylene of $1000 \mathrm{ml}$ rinsed in anticipation by the distilled water, then on the ground by the water of sample. Samples are transported in low temperature $\left(4^{\circ} \mathrm{C}\right)$ in a refrigerator to the laboratory. The nitrate, the complete nitrogen, the free chlorine and the ammonia were measured by a multi-parameter photometer Hanna C214. Turbidity was measured by an optical turbidimeter Hach $2100 \mathrm{~N}$. The material in suspension was filtered by a cellulosic filter and weighed after passage to the drying oven with $105^{\circ} \mathrm{C}$ [8].

We performed the measurement of $\mathrm{pH}$, redox potential, electrical conductivity, salinity, dissolved oxygen concentration, resistivity and temperature of the water using a multi-parameter analyzer type Consort C535 and Hanna instrument HI 98280.

The biological request of oxygen during five days $\left(\mathrm{DBO}_{5}\right)$ was measured by the apparatus DBOmeter OxiTop. As for chemical request of oxygen (DCO), was measured by DCOmeter type photometer Hanna C214. Besides, some mineral elements as the calcium $\left(\mathrm{Ca}^{2+}\right)$, the sodium $\left(\mathrm{Na}^{+}\right)$, the magnesium $\left(\mathrm{Mg}^{2+}\right)$, the potassium $\left(\mathrm{K}^{+}\right)$, chlorinates $\left(\mathrm{Cl}^{-}\right)$and the orthophosphate $\left(\mathrm{PO}_{4}^{3-}\right)$ are measured by a spectrophotometer.

\section{Results}

Measurements average, as well as the minima and maxima of the various organic and mineral physic-chemical parameters on which we based ourselves to characterize domestic wastewaters, rejected over the course of the river R'dom, are gathered in Tables 1 and 2.

With an aim of knowing if the organic matter is easily biodegradable, we calculated the ratios. The results are grouped in Table 3.

\section{Discussion}

The temperature and the $\mathrm{pH}$ are located at the interval of the Moroccan quality norms of waters intended for irri-

Table 1. Variation of the organic physicochemical parameters on the level of the two sites.

\begin{tabular}{|c|c|c|}
\hline Parameters & Collector 1 & Collector 2 \\
\hline $\mathrm{T}^{\circ} \mathrm{C}$ & $21.5 \pm 5.53$ & $20.95 \pm 5.21$ \\
\hline $\mathrm{pH}$ & $7.5 \pm 0.6$ & $7.2 \pm 0.8$ \\
\hline Dissolved oxygen (mg/l) & $0.82 \pm 0.49$ & $1.04 \pm 0.59$ \\
\hline Conductivity $(\mu \mathrm{S} / \mathrm{cm})$ & $2785 \pm 473$ & $2022 \pm 481$ \\
\hline Resistance $(\Omega-\mathrm{cm})$ & $684 \pm 104$ & $363 \pm 33.3$ \\
\hline Redox (mV) & $-44.7 \pm 65.49$ & $-57.2 \pm 59.62$ \\
\hline Turbidity (NTU) & $391 \pm 114$ & $509 \pm 485$ \\
\hline Salinity $(g / l)$ & $1.2 \pm 0.3$ & $0.7 \pm 0.4$ \\
\hline TDS (mg/l) & $1148 \pm 275$ & $720 \pm 153$ \\
\hline Pressure Atm (Pascal) & $1016 \pm 0$ & $1016 \pm 0$ \\
\hline $\mathrm{DBO}_{5}(\mathrm{mg} / \mathrm{l})$ & $353 \pm 216$ & $221 \pm 86$ \\
\hline DCO (mg/l) & $539.5 \pm 380.6$ & $751.5 \pm 339.8$ \\
\hline MES (mg/l) & $427.5 \pm 130.74$ & $421 \pm 75.6$ \\
\hline Free chlorine (mg/l) & $0.1 \pm 0.03$ & $1.9 \pm 0.29$ \\
\hline Nitrogenize total (mg/l) & $50.12 \pm 22.62$ & $67.9 \pm 36.87$ \\
\hline Ammonia $\left(\mathrm{NH}_{3}\right)$ & $60.65 \pm 17.92$ & $82.85 \pm 31.25$ \\
\hline Nitrate $\left(\mathrm{NO}_{3}^{-}\right)$ & $193.2 \pm 44.44$ & $321.6 \pm 117.4$ \\
\hline Hardness & $4.92 \pm 2.33$ & $6.6 \pm 2.33$ \\
\hline
\end{tabular}

Table 2. Variation of the concentration of some biogenic salts on the level of the two studied wastewaters.

\begin{tabular}{ccc}
\hline Parameters & Collector1 & Collector 2 \\
\hline $\mathrm{Na}^{+}(\mathrm{meq} / \mathrm{l})$ & $14 \pm 4.92$ & $2.7 \pm 3.7$ \\
$\mathrm{Cl}^{-}(\mathrm{meq} / \mathrm{l})$ & $0.45 \pm 0.30$ & $0.5 \pm 0.22$ \\
$\mathrm{~K}^{+}(\mathrm{meq} / \mathrm{l})$ & $18 \pm 2.94$ & $16 \pm 4.16$ \\
$\mathrm{PO}_{4}^{3-}(\mathrm{meq} / \mathrm{l})$ & $0.2 \pm 0.10$ & $0.21 \pm 0.11$ \\
$\mathrm{Mg}^{2+}(\mathrm{meq} / \mathrm{l})$ & $4 \pm 1.82$ & $5.8 \pm 2.18$ \\
$\mathrm{Ca}^{2+}(\mathrm{meq} / \mathrm{l})$ & $0.92 \pm 0.33$ & $0.8 \pm 0.15$ \\
$\mathrm{SAR}^{*}$ & $8.92 \pm 4.75$ & $6.99 \pm 3.45$ \\
\hline
\end{tabular}

*SAR: Sodium Adsorption Ratio. 
Table 3. Calculated Ratios from $\mathrm{DBO}_{5}$, DCO and MES.

\begin{tabular}{ccc}
\hline Ratios & Collector 1 & Collector 2 \\
\hline Oxidizable matter (mg/l) & 414.9 & 393.9 \\
$\mathrm{DCO} / \mathrm{DBO}_{5}$ & 1.53 & 3.39 \\
$\mathrm{DBO}_{5} / \mathrm{DCO}$ & 0.65 & 0.9 \\
${\mathrm{MES} / \mathrm{DBO}_{5}}$ & 1.21 & 1.9 \\
\hline
\end{tabular}

gation and for that of borders of direct rejections for $\mathrm{pH}$ included between 6.5 and 8.5 [9] what favor the development of microorganisms purifiers in aerobic and anaerobic environment. For the temperature, she is less in $30^{\circ} \mathrm{C}$ and allowable according to the quality of waters of surface, lower in $35^{\circ} \mathrm{C}$ for destination in irrigation [10, 11]. Our results comply with works accomplished in Oujda and in Kenitra [12-15].

Really, medium stocks of conductivity at the level of the collectors 1 and 2 are respectively in the order of $2785 \mu \mathrm{S} / \mathrm{cm}$ (limit norm of direct rejections: On 2700 $\mu \mathrm{S} / \mathrm{cm}$ ) and on $2022 \mu \mathrm{S} / \mathrm{cm}$. Our result recorded at the level of the collector 1 is slightly superior to that met to Oujda [12] and result signaled at the level of the collector 2 is less there. On the other hand, our results are similar to jobs to Valencia [16], to Jacksonville [17], and superiors to those found to Yaoundé [18].

Medium stocks of the salinity of the collectors 1 and 2 are respectively in the order of $1.21 \pm 0.29 \mathrm{~g} / \mathrm{l}$ and $0.7 \pm$ $0.36 \mathrm{~g} / \mathrm{l}$. These results are widely less than norm $(7.680$ $\mathrm{g} / \mathrm{l})$. The medium value of the dissolved oxygen by the collector 1 in the order of $0.82 \pm 0.49 \mathrm{mg} / \mathrm{l}$ is less than norm $(1 \mathrm{mg} / \mathrm{l})$ and that of the collector 2 is in the order of $1.04 \pm 0.59 \mathrm{mg} / \mathrm{l}$ correspondent to norm $(1 \mathrm{mg} / \mathrm{l})$, what is normal for these waters loaded in organic matter the deterioration of which by microorganisms asks for a consumption augmented by oxygen, our results are every inferiors to those found by Asia and Akporhonor [19].

Medium stocks of saturation in oxygen of both collectors 1 and 2 are respectively in the order of $12.6 \pm 6.81 \%$ and $13.6 \pm 10.65 \%$. Also for potential Redox is respectively in the order of $-44.72 \pm 65.49 \mathrm{mV}$ and $-57.16 \pm$ $59.62 \mathrm{mV}$. The negativity of potential redox explains due to the fact that the natural environment contracts a lack of oxygen.

In terms of TDS, medium stocks of both provoked collectors are respectively in the order of $1148 \pm 275.05 \mathrm{mg} /$ $\mathrm{l}$ and $720 \pm 152.51 \mathrm{mg} / \mathrm{l}$, exceeding results got in Nigeria [20]. The medium stocks of the turbidity of both collectors 1 and 2 are respectively in the order of $391 \pm 114.48$ NTU and $509 \pm 484.73$ NTU.

Medium stocks of DBO5 of both collectors 1 and 2 are respectively in the order of $352.6 \pm 215.97 \mathrm{mg}$ of $\mathrm{O} 2 / \mathrm{l}$ and $221.3 \pm 85.92 \mathrm{mg}$ of $\mathrm{O} 2 / \mathrm{l}$ who are superior to norm $25 \mathrm{mg}$ d' O2/l putting these domestic very charged wastewaters in quality very bad in organic matters. This polluting load is less than that recorded to Al Jadida [21]. The medium value of DBO5 at the level of the collector 1 is superior to that found to Oujda [12], itself superior to that recorded at the level of the collector 2 .

Medium stocks of MES of both collectors 1 and 2 are respectively in the order of $427.5 \pm 130.74 \mathrm{mg} / \mathrm{l}$ and 421 $\pm 75.6 \mathrm{mg} / \mathrm{l}$, by exceeding the limit concentration of direct rejection in the order of $50 \mathrm{mg} / \mathrm{l}$ [11]; so they are superior to results found at Oujda [12] and lower in stocks of Al Jadida [21].

Medium stocks of DCO of both collectors 1 and 2 are respectively in the order of $539,5 \mathrm{mg}$ of O2/l and 751.5 $\mathrm{mg}$ of O2/l, exceeding norm in the order of $80 \mathrm{mg} \mathrm{d}$, $\mathrm{O} 2 / \mathrm{l}$ returning these waters in very bad quality and are less than those recorded to the collector Sidi Dawi to $\mathrm{Al}$ Jadida [21] and superiors to those found in Oujda [12]. So, medium stocks of DCO of the collector 1 and 2 exceed limit stocks of direct rejections $50 \mathrm{mg}$ of O2/l.

Indeed medium stocks of both sites of sample are superior to limit value $80 \mathrm{mg}$ of O2/l of DCO of the quality grid of waters of surface and located in the very bad class. Stocks of DCO found in the collector 1 and 2 are superior to those got in Nigeria [20].

For the free chlorine medium value evolves from $0.1 \pm$ 0.03 to $1.9 \pm 0.29$ at the level of collectors 1 and 2 .

Medium stocks of the complete nitrogen of both collectors 1 and 2 are respectively in the order of $50.12 \mathrm{mg} / \mathrm{l}$ and $67.9 \mathrm{mg} / \mathrm{l}$, and those some ammonia are in the order of $65.65 \pm 17.92 \mathrm{mg} / \mathrm{l}$ and $82.85 \pm 31.25 \mathrm{mg} / \mathrm{l}$. These important results explain by an organic and mineral important load and they are superior to results got in Nigeria [20].

Medium stocks of the nitrate of both collectors 1 and 2 are respectively in the order of $193.2 \pm 44.44 \mathrm{mg} / \mathrm{l}$ and $321.6 \pm 117.4 \mathrm{mg} / \mathrm{l}$. They are superior to the quality norm of waters intended for irrigation $(50 \mathrm{mg} / \mathrm{l})$. And they are superior to work in Oujda [12]. The presence of the nitrate in the water is an indication of pollution of agricultural origin further to the use augmented by manure, by urban origin further to a dysfunction of networks of cleaning up, or by industrial origin. These values are much higher than the results got in Nigeria [20] concentration of oxygen decrease; middle becomes more reducing what is translated by a negative reduction of redox potential.

The biodegradability is the capacity of microorganisms to degrade the organic matter. The value of the report DCO/DBO5 at the level of the collector 2 is superior to the border 3 underlining an organic load badly biodegradable, contrary to that of the collector 1 which is less than the border 3 explaining that the organic matter is very biodegradable.

If DCO/DBO5 $=3$ this report underlines an organic load very biodegradable. However in rates of lower 
DBO5/DCO in 0.30; physicochemical techniques are more efficient than biological techniques [22].

The report DBO5/DCO gives important indications on the origin of the pollutions of employed waters and the proper treatment to be accomplished. In our study this report is high respectively at the level of collector 1 in the order of 0.65 and the collector 2 is in the order of 0.9 defining an unstable organic load which causes a clearing of smells.

Ratio MES/DBO5 explains that the material in suspension unsettles the oxygenation of middle and bacterial activity, this report is weak at the level of both domestic collectors.

SAR is the Ratio of the adsorption of the sodium expressing the relating activity of the ions of sodium in the reactions of exchange with the soil. When concentration of this and from Mg drops, in comparison the content of sodium and indication SAR what becomes more important what complicates the phenomenon of permeability of the soil as well as seepage; this will cause an effect of alcalinisation and augment the $\mathrm{pH}$. In our case SAR is less than norm 9 what allows these waters to be reused in irrigation.

Urban wastewaters of the city of Sidi Kacem introduce major physicochemical parameters of pollution exceeding relatively the general borders of the direct rejections, without prior treatment, directly in receiving middle by favoring the spread of water diseases, and the pollution of waters of surface and underground [23].

In the light of got results we deducted that most group of physicochemical parameters shows us the remarkable degree of the pollution of these effluents due to the fact that they exceed the borders of national and international norms.

The report DCO/DBO5 at the level of the collectors 1 and 2 is superior to 3 underlining an organic load badly biodegradable what asks for a chemical treatment as well as ratio of adsorption of sodium (SAR) does not exceed norm 9 what complies with irrigation.

Therefore it demands a type of treatment in a station of purification in the city of Sidi Kacem before the rejection of these wastewaters in the middle receiver under strict norms.

Concerning the treatment of these urban wastewaters, work is in hand focusing itself on the pretreatment in coagulation-flocculation.

The present study remains incomplete and must be completed by other investigations on microbiological, parasitological and metallic pollutions fields.

\section{REFERENCES}

[1] H. El Mostafa, "Effect of the Domestic and Industrial Liquid Wastes on the Quality of Groundwaters North of the Town of Settat (Morocco)," Bulletin of the Scientific
Institute, Folds Back, Section Life Sciences, No. 28, 2006, pp. 61-71.

[2] WHO, "The Re-Use of the Effluents: Methods of Medical Treatment of Waste Waters and Protection Measures," Series of Reports of WHO, No. 517, 1973, 68 p.

[3] M. Bzioui, "Report National 2004 on the Water Resources in Morocco,” 2004, 94 p.

[4] ONEP, "Report: Study of Cleansing of the Town of Sidi Kacem," 2006, 101 p.

[5] ABS, "Basin of Sebou Fès,” Morocco Agency, 2006.

[6] GCPH, "General Census of the Population and the Habitat,” Morocco, 2004.

[7] MEMEE, "State Quality Rivers Sebou Basin, Morocco," Minister for Energy, the Mines, Water and the Environment, Department of Water, 2000-2001.

[8] J. Rodier, "Analyzes; Natural Water, Waste Water, Sea Water,” 8th Edition, Denod, Paris, 1996, 1383 p.

[9] MEM, "Moroccan Standards, Official Bulletin of Morocco," Ministry of Environment of Morocco, Rabat, No. 5062, 2002.

[10] CSS, “Committee Standards and Standard,” Department of the Environment of Morocco, Folds Back, 1994.

[11] DRPW, "State of the Quality of the Water Resources in the Hydraulic Region of Sebou," Direction of the Research and the Planning of Water, Rabat, 1992-1993.

[12] M. Abouelouafa, H. El Halouani, M. Kharboua and A. Berrichi, "Physicochemical and Bacteriological Characterization of Rough Waste Waters of the Town of Oujda: Principal Channel and Wadi Bounaïm," Act Inst Agro et Vete Hassan II, Vol. 3, 2002, pp. 143-150.

[13] H. El Halouani, "Re-Use of Waste Waters in Agriculture and Their Impact on Environment: Case of the Oujda," Thesis State, Faculty of Science, Oujda, 1995.

[14] B. El Hamouri, M. Mekrane, K. Khallaayoune, Merzouki and M. El Maroufy, "Performances of Stabilization of the Station of Ouarzazate,” Acts of the Seminar: National Research in the Water Field and Environment, LPEE, Casa, 1993, pp. 261-268.

[15] S. Oulkheir, "Physico-Chemical and Microbiological Characteristics of Waste Waters of the Town of Kenitra," DESA, Kenitra, Faculty of Science, 2002, 79 p.

[16] A. Bes-Pia, J. A. Mendoza-Roca, M. I. Alcaina-Miranda, A. Iborra-Clar and M. I. Borra-Clar, "Reuse of Wastewater of the Textile Industry after Its Treatment with a Combination of Physic-Chemical Treatment and Membrane Technologies,” Desalination, Vol. 149, 2002, pp. 169174.

[17] L. B. Sonnenberg and J. C. Holmes, "Physic-Chemical Characteristics of Dissolved Organic Matter in Untreated and Treated Pulp and Paper Millet Wastewaters," International Proceedings TAPPI Environmental Conference, Vancouver, 1998.

[18] D. Endamana, I. M. Kengne, J. Gockowski, J. Nya, D. Wandji, J. Nyemeck, N. R. Soua and J. N. N. Bakwowi, "Wastewater Reuse for Urban and Periurban Agriculture in Yaounde Cameroon: Opportunities and Constraints," International Symposium on Water, Poverty and Produc- 
tive Uses of Water at the Household Level, Mulders Drift Transistor, South Africa, 2003.

[19] I. O. Asia and E. E. Akporhonor, "Characterization and Physicochemical Treatment of Waste Waters of the Factory of Transformation of Rubber," International Review of Physical Sciences, Vol. 2, No. 3, 2007, pp. 61-67.

[20] T. V. Otokunefor and C. Obiukwu, "Impact of Refinery Effluent on the Physic-Chemical Properties of a Water Body in the Niger Delta," 2005.

[21] Y. Salama, Mr. Mountadar, M. Rihani and O. Assobhei, "Physico-Chemical and Bacteriological Evaluation of Rough Waste Waters of the Town of El Jadida (Moroc- co)," Science Lib Editions Mersenne, Vol. 4, 2012, Article ID: 120906.

[22] H. Alvares-Vazquez, B. Jefferson and S. J. Judd, "Membrane Bioreactors vs, Conventional Biological,” Journal of Chemical Technology and Biotechnology, Vol. 79, No. 10, 2004, pp. 1043-1049.

http://dx.doi.org/10.1002/jctb.1072

[23] MRPWE, "National Plan of the Water of Morocco," Ministry of Regional Planning, Water and of Environment, Acts Regional Paper Seminar on the National Plans of Water, Rabat, 2006. 